\title{
Possible ways of obtaining an aluminium alloy by non-traditional waste processing of alumin- ium beverage containers
}

Štefan Michna, Petr Majrich

Department of Technologies and Material Engineering, Faculty of Production Technologies and Management, Jan Evangelista Purkyně University in Ústí nad Labem, Czech Republic. E-mail: michna@fvtm.ujep.cz.

The aim of this experiment was to melt down aluminium beverage containers and making use of the recycling process to acquire an aluminium material of a certain chemical composition for another production process with the aim of manufacturing aluminium semi-products and products. The aluminium material extracted in this way was subsequently analysed chemically and metallographically. These experiments were carried out within three casts and in all three cases the batch was formed by $100 \%$ of aluminium scrap in the form of finely shredded aluminium cans (Fig.1) and from the point of view of the complex efficiency assessment of the recycling process a calculation of the yield of the acquired aluminium alloy was undertaken. At the same time, considering that the aluminium waste was coated with plastic materials, paper and varnish/lacquer, it was necessary to identify the content and compositions of the substances released in the course of the melting process in the form of gas and assess their possible negative impact on the environment.

Keywords: aluminium alloy, beverage containers

\section{References}

[1] LUKAC, I., GRUTKOVA, J. Vlastnosti a struktura nezeleznych kovov II, Alfa 1975.

[2] BOLIBRUCHOVA, D. - TILLOVA, E. Zlievarenske zliatiny Al-Si, ZU v Ziline - EDIS, 2005, ISBN 80-8070485-6.

[3] MONDOLFO, L. F. Aluminium Alloys, Structure and Properties, Butterworths, London 1979.

[4] MICHNA, S., LUKAC, I. a kol. Encyklopedie hliniku, 720 str., Adin s.r.o., Prešov SR, 2005, ISBN 80-89041$88-4$.

[5] MICHNA, S, LUKAC, I., Barevny kontrast, struktury a vady u hliniku a jeho slitin, 214 str. Delta Print, Decin CR, ISBN 80-239-1636-X.

[6] LUKAC, I.; MICHNA, S. Colour Contrast, Structure and Defects in Aluminium and Aluminium Alloys, pp. 168, September 2001, Cambridge International Science Publishing GB, ISBN 1-898326-70-3.

[7] MICHNA, S., MAJRICH, P. Nove poznatky o strukture slitiny AlSi12CuMgNi (Transactions of the VŠB Technical University of Ostrava, Metallurgical Series 1/2007, pp. 163 -173, ISBN 978-80-248-1748-0, ISSN 1210-0471).

[8] MICHNA S, NAPRSTKOVA N.: Research into the causes cracking of aluminum alloys of $\mathrm{Al}-\mathrm{Cu}$ during mechanical machining, Manufacturing Technology, vol. 12, No. 12, June 2012, str. 47-51, ISSN 1213-2489

[9] MICHNA S., KUSMIERCZAK S.: Technologie a zpracovani hlinikovych materialu, Vydavatel: Fakulta vyrobnich technologii a managementu UJEP, Usti nad Labem kveten 2008, ISBN 978 -80 - 7044- 998 - 1.

[10] VAJSOVA, V., MICHNA, S.: Optimization of AlZn5,5Mg2,5Cu1,5 Alloy Homogenizing Annealing. Metallofizika i Noveishie Teknologii, Volume 32, No 7, July 2010, str. 949 - 959, ISSN 1024-1809

[11] MICHNA, S., NAPRSTKOVÁ, N., LUKÁČ I. : Mechanical Properties Optimization of AlSi12CuMgNi Alloy by Heat Treatment, Metallofizika i Noveishie Teknologii, 11 / 2011, ISSN 1024-1809

[12] LUKAC I., MICHNA, S.: Colour Contrast, Strukture and Defects in Aluminium and Aluminium Alloys, Cambridge international science publishing, september 2001, GB, ISBN 18 98326-70-3

Paper number: M201236 